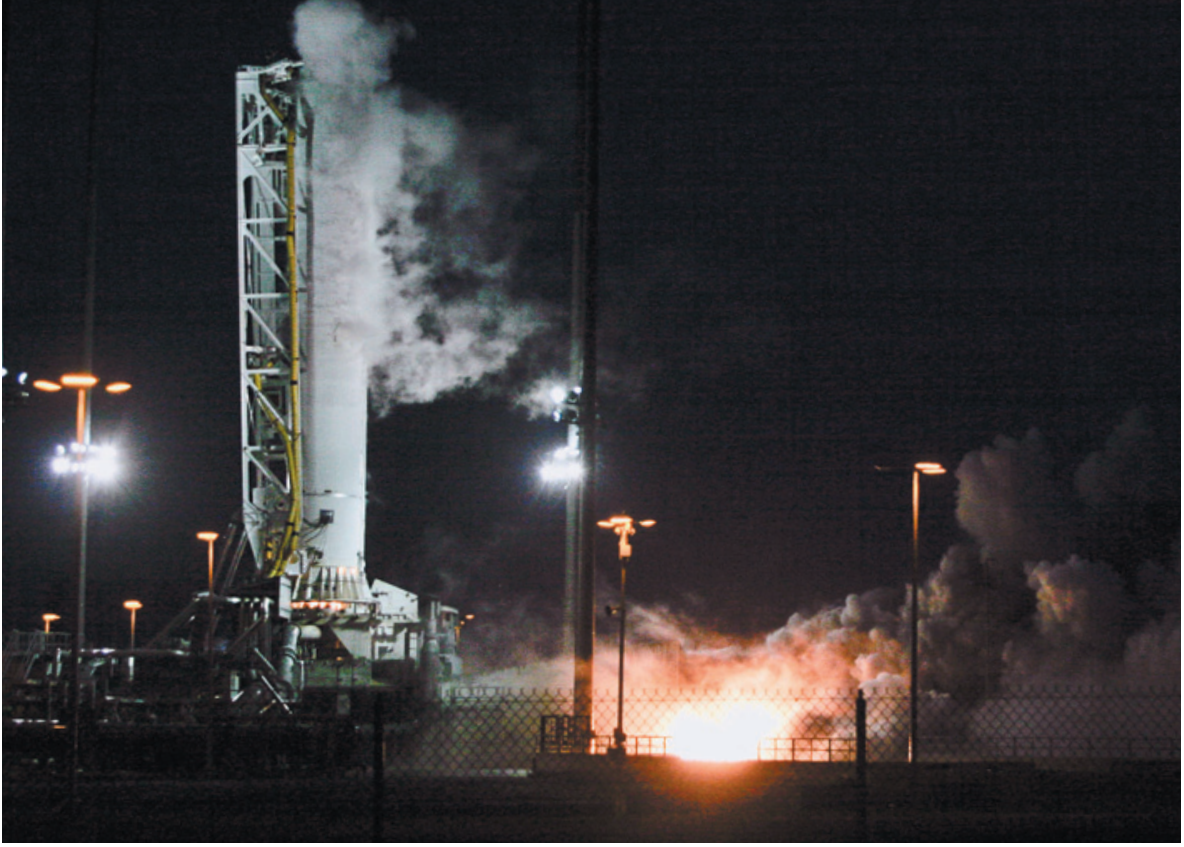

A successful engine test last month means that the Antares rocket can proceed to its inaugural launch.

SPACE FLIGHT

\title{
Commercial space race heats up
}

\section{Antares test could challenge dominance of Falcon 9 rocket.}

\section{BY DEVIN POWELL}

$\mathrm{T}$ The Falcon 9 rocket, which made its fifth successful flight on 1 March, has stolen the spotlight in the commercial space race. Built by SpaceX, a young company based in Hawthorne, California, the rocket has become NASA's choice for hauling cargo to the International Space Station (ISS). But it may soon have competition from a rocket that has kept a low profile (see 'Battle of the rockets').

After years of delays, Orbital Sciences of Dulles, Virginia, has slated the first test flight of its Antares rocket for April. If that goes well, its second mission could carry an unmanned Cygnus spacecraft to the ISS within months. "There's no one main problem, no showstopper," says Orbital spokesman Barron Beneski. "In hindsight, this has just taken us longer to do than we thought it would."

Both companies have received hundreds of millions of dollars from NASA's Commercial Orbital Transportation Services (COTS) programme. With the space shuttle retiring in 2011, the agency wanted alternatives to paying for ISS deliveries aboard the Russian Progress and Soyuz craft. NASA deliberately put two companies in competition with each other to keep prices down over the long run and to attract other customers. "The government is the necessary anchor tenant for commercial cargo, but it's not sufficient to build a new economic ecosystem," says Scott Hubbard, an aeronautics researcher at Stanford University in and built by veterans KB Yuzhnoye and Yuzhmash, both based in Dnipropetrovsk, Ukraine. Cygnus's sensors come from Mitsubishi Electric in Tokyo and its pressurized cargo module was built at a Thales Alenia Space plant in Turin, Italy. "Orbital used more heritage technology," says Alan Lindenmoyer, manager of NASA's commercial crew and cargo programme. "That was less risky for us."

But the company did not enter COTS until 2008 , two years after SpaceX. With the clock ticking, NASA allocated less money for Orbital and ordered a simpler ship. Unlike SpaceX's Dragon capsule, Cygnus can't carry sensitive biological experiments, such as those that grow protein crystals in microgravity. It burns up on re-entry, so it can't return samples to Earth. And it can't be modified to carry humans.

Nor has it yet flown. Orbital chose to launch from NASA's Wallops Flight Facility in Virginia; less crowded than Cape Canaveral in Florida, which hosts most NASA rocket launches, Wallops usually caters for smaller vehicles such as scientific balloons and sounding rockets. The facility's Mid-Atlantic Regional Spaceport had to build a new launch pad for Antares, which took longer than expected. Originally scheduled for 2010, the demonstration launch slipped to 2012, and then to 2013, after Hurricane Sandy hit the spaceport last October.

Antares' engines, built half a century ago for Russia's Moon programme and recently refurbished, have also proven finicky. A test on 13 February was aborted when pressure anomalies were detected in one of the engines. A successful test on 22 February means that Orbital can now proceed to a launch in April.

Having another cargo carrier would provide a safety net for the ISS. That need was made clear when Dragon's thrusters initially failed during the flight last week, almost preventing the spacecraft from docking with the station. But there is scepticism about whether competition will drive down prices. "This is a mixedup crazy business and a small market that isn't all that price sensitive," says Henry Hertzfeld, a space-policy expert at George Washington University in Washington DC.

Factors such as political or military concerns often shape demand, he says. And reliability is as much of a concern as price. The market could grow: private space stations, orbiting fuel depots and asteroid-mining operations have all been proposed as future clients for commercial rockets. But for now, supplying the ISS and launching satellites are the major niches.

SpaceX is making inroads with the latter: it has contracts for launches with the US Air Force and commercial operators in Israel, Thailand, Luxembourg and Mexico. Orbital, too, wants to develop business beyond NASA, but it has not yet booked any launches. "Right now, we're focused on getting the rocket launched," says Frank Culbertson, executive vice-president of Orbital's advanced-programmes group. "Then we can talk to other customers." - 